УДК 338.64

Коренюк Петро,

доктор економічних наук, професор,

Дніпровський державний технічний університет, завідувач кафедри менеджменту організацій і адміністрування,

м. Дніпро; e-mail: korenyukp@gmail.com

Усикова Олена,

доктор економічних наук, доцент,

Миколаївський національний аграрний університет, в. о. директора навчально-наукового інституту економіки та управління, м. Миколаїв; ORCID ID 0000-0001-6734-5757, e-mail: elenamb73@ rambler.ru

https://doi.org/10.29038/2411-4014-2020-02-83-89

\title{
УДОСКОНАЛЕННЯ МЕТОДИЧНИХ ПІДХОДІВ ДО СИСТЕМИ УПРАВЛІННЯ ВЛАСНИМ КАПІТАЛОМ ПІДПРИЕМСТВ
}

Формування структури власного капіталу на багатьох приватних підприємствах здійснюється інтуїтивно, або згідно з традиціями, без належного аналітично-математичного обгрунтування. В даній ситуації різко підвищується значимість управління власним капіталом. Від того, наскільки ефективно та доцільно він трансформується в основні та оборотні активи, залежить фінансовий добробут підприємства в цілому, його власників та робітників.

Підвищення результативності підприємницької діяльності забезпечує зростання економічного потенціалу держави і навпаки - виникнення кризових явищ на окремих підприємствах негативно відбивається на економічній системі в цілому. За таких умов саме підприємство повинно стати у центрі подальших економічних реформ 3 метою створення функціонально ефективної, стратегічно зорієнтованої та демократичної економіки.

Ключові слова: власний капітал, ефективність управління, управлінськи рішення, критерії ефективності, рентабельності власного капіталу.

Коренюк Петр, доктор экономических наук, профессор, Днипровский государственный технический университет, заведующий кафедрой менеджмента организаций и администрирования, г. Днипро

Усикова Елена, доктор экономических наук, доцент, и.о. директора учебно-научного института экономики и управления, Николаевского национального аграрного университета, г. Николаев

\section{УСОВЕРШЕНСТВОВАНИЕ МЕТОДИЧЕСКИХ ПОДХОДОВ К СИСТЕМЕ УПРАВЛЕНИЯ СОБСТЕННЫМ КАПИТАЛОМ ПРЕДПРИЯТИЙ}

Формирование структуры собственного капитала на многих частных предприятиях осуществляется интуитивно, или согласно установленным традициям, как правило, без должного аналитическиматематического обоснования. В данной ситуации резко повышается значимость управления собственным капиталом. От того, насколько эффективно и целесообразно он трансформируется в основные и оборотные активы, зависит финансовое благополучие предприятия в целом, его владельцев и работников.

Повышение результативности предпринимательской деятельности обеспечивает рост экономического потенциала государства и наоборот - возникновение кризисных явлений на отдельных предприятиях негативно отражается на экономической системе в целом. При таких условиях само предприятие должно стать в центре 
дальнейших экономических реформ с целью создания функционально эффективной, стратегически ориентированной и демократической экономики.

Ключевые слова: собственный капитал, эффективность управления, управленческие решения, критерии эффективности, рентабельноти собственного капитала.

Korenyuk Peter, Doctor of Economics, Professor, Head of the Department of Management of Organizations and Administration, Dnieper State Technical University, Dnipro city

\author{
Usykova Elena, \\ Doctor of Economics, Associate Professor, \\ Nikolaev National Agrarian University, \\ Director of the Educational and Scientific Institute of Economics and Management
} Nikolaev

\title{
IMPROVEMENT OF METHODICAL APPROACHES TO THE CAPITAL MANAGEMENT SYSTEM OF ENTERPRISES
}

The formation of the structure of equity in many private enterprises is carried out intuitively, or according to tradition, without proper analytical and mathematical justification. In this situation, the importance of managing your own equity rises sharply. The financial well-being of the enterprise as a whole, its owners and employees, depends on how efficiently and appropriately it is transformed into fixed and current assets.

Improving the effectiveness of entrepreneurial activity ensures the growth of the economic potential of the state and vice versa - the emergence of crisis phenomena at individual enterprises negatively affects the economic system as a whole. Under such conditions, the enterprise itself should become the center of further economic reforms in order to create a functionally effective, strategically oriented and democratic economy.

Keywords: equity, efficiency of management, managerial decisions, efficiency criteria, return on equity.

Постановка проблеми. Власний капітал є основою для початку і продовження господарської діяльності будь-якого підприємства. Дослідження методичних підходів щодо управління власним капіталом підприємств в умовах ринкових відносин є дуже актуальним.

Однією із найважливіших проблем, 3 якою стикаються вітчизняні підприємства, є недостатня ефективність організації управління власним капіталом. 3 огляду на те, що власний капітал найважливіший чинник економічного зростання, організацію управління власним капіталом підприємств необхідно трактувати як основну ланку усього комплексу заходів, спрямованих на його забезпечення.

Аналіз останніх досліджень і публікацій. Теоретичною методологічною основою роботи $є$ основні положення і висновки, сформульовані в наукових фундаментальних працях вітчизняних i закордонних спеціалістів, а саме Крейніної М.Н., Ковальова В.В., Антони Р.Н.,.Модільяні Ф., Міллєра М. та ін.

Становлять інтерес визначення власного капіталу організації, що приводять у сучасній літературі. Так, наприклад, американський економіст Антони Р.Н. вважає, що власний капітал підприємств є результатом інвестицій з боку інвесторів-співвласників цього підприємства (за умови, що компанія не має зобов'язань по поверненню внесеного капіталу своїм інвесторам). В той же час вітчизняні економісти (Белобжецький И.А., Блатов Н.А,. Вейцман Н.Р. й ін.) відзначають, що власний капітал - це властива умовам ринкової економіки категорія, що замінила традиційне поняття «джерела власних коштів підприємства». П. С. Безруких уважає, що «власний капітал підприємства як юридичної особи або відособленого господарюючого суб'єкта в загальному виді визначається вартістю майна, що належить підприємству, це так звана чиста вартість майна. Вона дорівнює різниці між вартістю майна й позиковим капіталом». 
Виділення невирішених раніше частин загальної проблеми. Дослідження моделей та методичних підходів щодо управління власним капіталом в умовах мінливих нестабільних економічних відносин . До завдань роботи відносяться визначення теоретичних та методичних підходів щодо управління власним капіталом підприємства та дослідження системи показників оцінки ефективності використання власного капіталу і сучасних моделей управління капіталом підприємства в умовах не стабільного економічного становища країни.

Викладання основного матеріалу. Під організацією управління власним капіталом підприємницькими товариствами потрібно розуміти створення ефективної управлінської системи та iї постійне удосконалення. Саме таке завдання і має вирішувати організація, яка схематично подана на рисунку 1.

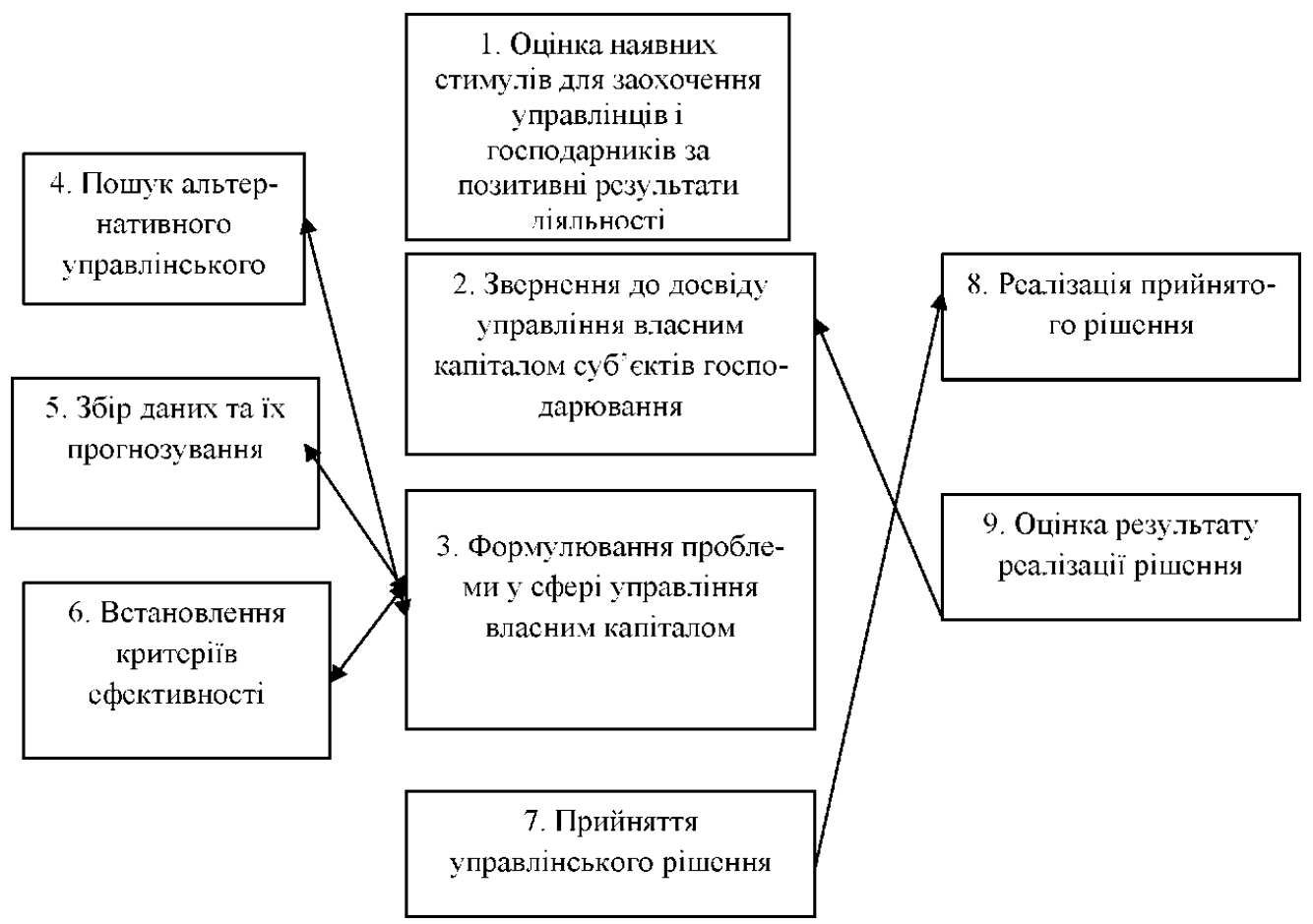

Рис. 1. Схема організації управління власним капіталом суб'єктів господарювання

Таке розуміння сутності організації дає можливість: чітко визначити проблему та ціль діяльності системи управління; вибрати правильний об'єктивний спосіб дослідження складних економічних процесів; відібрати комплекс методів і засобів, що дають змогу досягнути поставленої мети шляхом проектування здатної до адаптації економічної системи; побудувати та забезпечити функціонування цієї системи.

Проаналізуємо докладніше кожен етап процесу організації управління власним капіталом підприємства.

1. Оцінка наявних стимулів для заохочення управлінців і господарників за позитивні результати діяльності.

2. Звернення до минулого досвіду управління власним капіталом підприємства, а також до позитивного досвіду інших господарюючих суб'єктів, як вітчизняних, так і зарубіжних.

3. Одним з основних етапів процесу організації управління власним капіталом є формулювання проблеми у тій сфері діяльності, де виявлені проблеми використання власного капіталу.

- Розглянувши різні підходи науковців, ми виявили, що капітал є поняттям багатогранним. Загалом - це фінансово-економічні ресурси підприємства, що використовуються для фінансування як матеріальних, так і не матеріальних активів (інформаційні, основні засоби, запаси товарів тощо) 3 метою постійного збільшення вартості капіталу. Існує надзвичайно велика кількість класифікаційних ознак капіталу, проте загалом їх можна розділити на три основні групи - за джерелами залучення, за формами залучення та за характером використання. Найкраще, на нашу думку, можна підкреслити роль капіталу для підприємства на прикладі видів капіталу в залежності від використання у 
виробничому процесі - оборотний та основний. Капітал використовується власне для фінансування ефективної діяльності підприємства, що й забезпечує постійне розширене відтворення останнього, а це у свою чергу забезпечує зростання вартості капіталу.

- Формування капіталу акціонерного товариства відрізняється від тотожного процесу на підприємствах іншого організаційно-правового типу лише у частині формування власного капіталу. Так у акціонерному товаристві весь капітал суб'єкта господарювання ділиться на акції, мінімальний розмір статутного капіталу становить 1250 мінімальних заробітних плат. Вітчизняне законодавство чітко регламентує процес збільшення обсягу власного капіталу підприємства та його зменшення. Що ж до формування позикового капіталу у акціонерному товаристві, то цей процес $\epsilon$ типовим i відбувається за рахунок залучення банківських кредитів та кредитів небанківських фінансових установ, комерційних кредитів, у формі емісії цінних паперів, у формі одержаних послуг тощо. Власний та позиковий капітал характеризуються своїми як позитивними, так і негативними якостями, а тому при формуванні фінансової структури капіталу необхідно підходити індивідуально до потреб конкретного акціонерного товариства.

Організація системи управління власним капіталом підприємства має забезпечити розв'язання проблем недостатності оборотного капіталу; труднощів при здійсненні розрахунків із постачальниками; різкого зменшення кількості замовлень, зменшення обсягу продажу через появу нових конкурентів; наявності збитків; заборгованості в розрахунках за банківськими відсотками; появи негативного іміджу підприємства на ринку; конфлікту між ланками керівництва підприємства; звільнення висококваліфікованих працівників.

4. Пошук альтернативного управлінського рішення.

5. Збір даних та їх прогнозування.

6. Встановлення критеріїв ефективності.

7. Прийняття управлінського рішення.

8. Реалізація прийнятого рішення.

9. Оцінка результату реалізації рішення.

На підставі аналізу основними недоліками організації власного капіталу підприємств є:

1. Підприємство функціонує в основному за рахунок власних коштів.

2. Недостатнє забезпечення додатковим та резервним капіталом.

3. Відсутність значних нововведень та нових інвестицій.

4. Значне зниження нерозподіленого прибутку.

5. Низький показник рентабельності власного капіталу .

Усі ці чинники значною мірою можуть вплинути на діяльність підприємств у майбутніх періодах. Зниження конкурентоздатності, застаріння обладнання та технологій, а звідси і зниження прибутковості, рентабельності тощо.

Як відомо, використання підприємствами лише власного капіталу має не лише позитивні, а й негативні риси:

- обсяг власного капіталу обмежений тому підприємство може втратити можливість розширення діяльності та збільшення рентабельності за рахунок залучення позикових коштів;

- часто власний капітал, що залучений із зовнішніх джерел, має більш високу вартість порівняно із позиковим капіталом.

Головною метою діяльності підприємства $є$ максимізація прибутку. Тому край необхідно залучити коротко- або довгострокові позики. Оптимальним варіантом формування фінансів підприємства вважається наступне співвідношення: частка власного капіталу повинна бути більше або дорівнює 60\%, а частка позикового капіталу - менше або дорівнює $40 \%$.

Тобто в першу чергу підприємству слід залучити для своєї господарської діяльності позикові кошти. Так як використання лише власних коштів не може достатньо розвивати виробництво, а в подальшому знизить рентабельність, фінансову стійкість товариства. Збільшення капіталу може відбуватися за допомогою реінвестування прибутку усередині компанії.

Для поліпшення фінансового стану й удосконалення організації власного капіталу підприємств можуть бути використані наступні шляхи прискорення оборотності капіталу:

1) Залучення позикових коштів для розвитку виробництва та росту прибутку; 
2) Скорочення тривалості виробничого циклу за рахунок інтенсифікації виробництва (використання новітніх технологій, механізації й автоматизації виробничих процесів, підвищення рівня продуктивності праці, більше повне використання виробничих потужностей підприємства, трудових і матеріальних ресурсів й ін.);

3) Поліпшення організації матеріально-технічного постачання 3 метою безперебійного забезпечення виробництва необхідними матеріальними ресурсами й скорочення часу знаходження капіталу в запасах;

4) Прискорення процесу відвантаження продукції й оформлення розрахункових документів;

5) Скорочення часу знаходження коштів у дебіторській заборгованості;

6) Підвищення рівня маркетингових досліджень, спрямованих на прискорення просування товарів від виробника до споживача (включаючи вивчення ринку, удосконалювання товару й форм його просування до споживача, формування правильної цінової політики, організацію ефективної реклами й т. п.);

7) Створення більшого резервного фонду, а також удосконалювання його обліку й відбиття в бухгалтерському балансі.

Сучасне економічне становище потребує від власників та фінансових менеджерів підприємств ефективного управління, уважного контролю та своєчасного коригування структури капіталу підприємства, бо оптимальна структура капіталу дозволяє отримувати максимальний прибуток, рентабельність, фінансову стійкість та високі показники ліквідності та платоспроможності. Для контролю за поточним станом структури капіталу необхідно регулярно визначати показники ефективності управління капіталом підприємства.

Діяльність підприємства в умовах будь-якої форми власності, організаційно-правового статусу і галузевої спрямованості безпосередньо залежить від фінансового капіталу та його структури. Досягнення стратегічних цілей підприємства також значно залежить від ефективності управління капіталом підприємства та його структурою, тобто визначення загальної потреби в них, формування оптимальної структури, умов їх залучення.

Кожне підприємство прагне управляти фінансовим капіталом та його структурою, тобто досягнути такого співвідношення внутрішніх та зовнішніх джерел коштів, яке б здійнювало максимальний позитивний вплив на досягнення його стратегічних цілей.

Доцільніше за все для забезпечення кращого співвідношення власного і позикового капіталу поєднати усі із запропонованих моделей воєдино, що дозволить досягти найвищих показників господарської діяльності підприємства.

Перш за все запозичимо ідею послідовників традиційного та компромісного підходів. При невеликих позиках ймовірність розорення низька і витрати банкрутства також невеликі. Тобто слід впровадити помірне зростання позикових коштів, тобто деяке підвищення фінансового ризику, яке приведе до оптимальної структури капіталу, росту виробництва та ін. Загальна рекомендація щодо компромісного підходу зводиться до того, що 100\%-й позиковий капітал, і виключно власне фінансування $є$ неоптимальними стратегіями управління.

- Щодо методичних особливостей управління підприємством у зарубіжних підприємствах, то тут ми звернули увагу на вартісно-орієнтоване управління - процес, ціль якого $є$ власне збільшення вартості капіталу. Тут ми рекомендуємо українським суб'єктам господарюванням використовувати такі фінансові показники, як EVA, MVA, SVA, DCF тощо, що дозволяють не лише відслідковувати зміну вартості підприємства, а й формувати систему фінансових індикаторів, що забезпечать максимально швидке досягнення поставлених цілей приросту вартості капіталу. Перелічені аспекти управління капіталом можна назвати зарубіжним досвідом лише умовно - вітчизняні підприємства також здійснюють первинне розміщення акцій, використовують інструменти хеджування ризиків та використовують вартісно-орієнтоване управління підприємством. Проте якщо в Україні така практика не поширена, то в зарубіжній практиці - ці інструменти є важливими у щоденній практиці для будь-якого підприємства.

Рекомендацією сигнальної моделі Майерса-Майлуфа 1984p. по формуванню цільової структури капіталу є також підтримання запасу позикової потужності для залучення капіталу.

М. Н. Крейніна підходить до управління структурою капіталу підприємства з позиції фінансової стійкості підприємства. 
Згідно іï підходу, стійке фінансове становище підприємства визначається достатньо високим рівнем коефіцієнтів поточної ліквідності та забезпеченості власними коштами. Перший 3 коефіцієнтів збільшується при відносно більш високих темпах росту капіталу і резервів у порівнянні 3 темпами росту короткострокової заборгованості.

Висновки та пропозиції. Ми вважаємо, що стійке фінансове становище підприємства визначається також високою рентабельністю капіталу. Від цього залежить інвестиційна привабливість підприємства, рівень дивідендів на акції. Але при інших рівних умовах рентабельність капіталу тим вище, чим менше його сума. При заміщенні частини власного капіталу позиковим рентабельність капіталу підвищується.

Тому, 3 одного боку, підприємство не може безмежно збільшувати короткострокову заборгованість (максимальний ii обсяг у відповідності 3 офіційно встановленим коефіцієнтом ліквідності, що дозволяє вважати підприємство платоспроможним, повинен бути вдвічі менше величини оборотних активів).

Краще користуватися довгостроковими позиками, ніж короткостроковими. Однак в сучасних умовах така рекомендація носить в основному теоретичний характер: довгострокові кредити i позики, як правило, надаються підприємствам в дуже обмежених розмірах, а частіше взагалі не надаються.

Є. С. Стоянова пропонує деякі положення:

1. Підприємство, що використовує лише власні кошти, обмежує їхню рентабельність приблизно $2 / 3$ економічної рентабельності.

2. Підприємство, що використовує кредит, збільшує або зменшує рентабельність власних коштів, в залежності від співвідношення власних та позикових коштів у пасиві та від величини відсоткової ставки.

Отже, раціональний підхід щодо ефективного управління капіталом підприємства та його структурою має базуватися на побудові балансових моделей оцінки фінансового стану підприємства. За настання абсолютної фінансової стійкості підприємство не використовує переваг які має зовнішнє фінансування при цьому обмежуючи зростання обсягів своєї діяльності.

Оптимальною будемо вважати другу модель: нормальна фінансова стійкість: за умови, що ВОК $<$ ЗВ < НДФЗ. Коли на підприємстві застосовується ефективна політика залучення та використання позикових коштів, виробничі потреби підприємства в повному обсязі забезпечуються різноманітними джерелами фінансування (ВОК, короткострокові банківські кредити та позики для покриття оборотних активів, розрахунки з кредиторами за товари, роботи, послуги), строк сплати яких не настав.

Таким чином, наявність цілої низки підходів щодо проблеми ефективності управління капіталом та його структурою обумовлена неоднозначним впливом структури капіталу на різноманітні аспекти його діяльності. Головним критерієм $є$ управління співвідношенням власних і позикових коштів. Отже, головним завданням фінансових менеджерів для підприємств $\epsilon$ оптимізація даного співвідношення, вибір надійних кредиторів для росту залучених коштів. А це в свою чергу дасть новий потенціал для підприємства і виробництва, ріст конкурентоспроможності і стійкості.

\section{Джерела та література}

1. Деркач Т. В. Збільшення статутного капіталу ТОВ: додаткові внески та штрафні санкції. Бухгалтерія. 2018. - №35. 74c.

2. Марковський С. Н. Аналіз діяльності підприємств. Економіка України. К., 2019, № 2, 35с.

3. Фролова Т.О. Фінансовий аналіз: Навчально методичний посібник для самостійного вивчення $\mathrm{i}$ практичних занять: - К.: Вид-во Європ.ун-ту, 2018. - 253с.

4. Энтони Р., Рис Дж. Облік ситуації приклади: перев. з англ. /Гл. ред.Я.В.Соколов.-М. 1993.- 234c.

5. Яремко І. Й. Управління капіталом підприємства: економічний і фінансовий інструментарій : монографія. - Львів : Вид-во "Каменяр", 2018. - 176с.

6. Електронный ресурс: Державна установа "Агентство з розвитку інфраструктури фондового ринку України" www.smida.gov.ua

7. Електронный ресурс: сайт Загальнодоступної інформаційної бази даних Державної комісії з цінних паперів та фондового ринку про ринок цінних паперів www.stockmarket.gov.ua 
8. Електронный ресурс: сайт "Законодавство України" www.zakon.rada.gov.ua

\section{References}

1. Derkach, T.V. (2018). Zbilshennia statutnoho kapitalu TOV: dodatkovi vnesky ta shtrafni sanktsii [Increase of the authorized capital of the LLC: additional contributions and penalties]. Accounting, 35, 74p. [in Ukrainian].

2. Markovsky, S.N. (2019). Analiz diialnosti pidpryiemstv [ Analysis of enterprise activity ]. Economy of Ukraine, Kyiv: 2, 35p. [in Ukrainian].

3. Frolov, T.O. (2018). Finansovyi analiz: Navchalno metodychnyi posibnyk dlia samostiinoho vyvchennia i praktychnykh zaniat [Financial analysis: A manual for self-study and practical training]. Kyiv: European University Edition, 253p. [in Ukrainian].

4. Anthony, R., Figure, J. (1993). Oblik sytuatsii pryklady [Situation accounting examples]. [in Ukrainian].

5. Yaremko II (2018). Upravlinnia kapitalom pidpryiemstva: ekonomichnyi i finansovyi instrumentarii [Enterprise capital management: economic and financial tools]. Lviv: Kamyanar Publishing House, 176 p. [in Ukrainian].

6. Ahentstvo z rozvytku infrastruktury fondovoho rynku [Stock Market Infrastructure Development Agency of Ukraine]. Retrieved from www.smida.gov.ua / [in Ukrainian].

7. Zahalnodostupna informatsiina baza danykh Derzhavnoi komisii z tsinnykh paperiv ta fondovoho rynku pro rynok tsinnykh paperiv [Information Database of the State Commission on Securities and Stock Market about the securities market]. Retrieved from www.stockmarket.gov.ua / [in Ukrainian].

8. Zakonodavstvo Ukrainy [Legislation of Ukraine]. Retrieved from www.zakon.rada.gov.ua / [in Ukrainian]. 